\title{
Assessment of Aqueous Extraction Methods on Extractable Organic Matter and Hydrophobic/Hydrophilic Fractions of Virgin Forest Soils
}

\author{
Wan Muhammad Ikram Wan Mohd Zamri ${ }^{1}$ (1) , Fridelina Sjahrir ${ }^{1}$, Nor Suhaila Yaacob ${ }^{2,3, *}$ (D), \\ Noor Fazreen Dzulkafli ${ }^{1}\left({ }^{10}\right.$, Mohd Fadzli Ahmad ${ }^{1}{ }^{(\mathbb{C}}$, Hasdianty Abdullah ${ }^{1,3}$, Maegala Nallapan Maniyam ${ }^{2,3}{ }^{(0)}$, \\ Emi Fazlina Hashim ${ }^{1}$, Nobuyuki Kawasaki ${ }^{4}$, Kazuhiro Komatsu ${ }^{5}$ and Victor S. Kuwahara ${ }^{6}$ (D)
}

1 Department of Science \& Biotechnology, Faculty of Engineering \& Life Sciences, Universiti Selangor, Bestari Jaya 45600, Selangor, Malaysia; ikramzamri1995@gmail.com (W.M.I.W.M.Z.); fridelina@unisel.edu.my (F.S.); fazreen@unisel.edu.my (N.F.D.); fadzli@unisel.edu.my (M.F.A.); dianty@unisel.edu.my (H.A.); hashim.emifazlina@nies.go.jp (E.F.H.)

2 Institute of Bio-IT Selangor, Universiti Selangor, Jalan Zirkon A7/A, Seksyen 7,

Shah Alam 40000, Selangor, Malaysia; maegala@unisel.edu.my

3 Centre for Foundation and General Studies, Universiti Selangor, Jalan Zirkon A7/A, Seksyen 7, Shah Alam 40000, Selangor, Malaysia

check for updates

Citation: Wan Mohd Zamri, W.M.I.; Sjahrir, F.; Yaacob, N.S.; Dzulkafli, N.F.; Ahmad, M.F.; Abdullah, H.; Maniyam, M.N.; Hashim, E.F; Kawasaki, N.; Komatsu, K.; et al. Assessment of Aqueous Extraction Methods on Extractable Organic Matter and Hydrophobic/ Hydrophilic Fractions of Virgin Forest Soils. Molecules 2021, 26, 2480. https://doi.org/10.3390/ molecules 26092480

Academic Editor: Riccardo Spaccini

Received: 1 March 2021

Accepted: 16 April 2021

Published: 23 April 2021

Publisher's Note: MDPI stays neutral with regard to jurisdictional claims in published maps and institutional affiliations.

Copyright: (c) 2021 by the authors. Licensee MDPI, Basel, Switzerland. This article is an open access article distributed under the terms and conditions of the Creative Commons Attribution (CC BY) license (https:/ / creativecommons.org/licenses/by/ $4.0 /)$.
4 Dainippon Ink and Chemicals DIC Corporation, Central Research Laboratories, 631 Sakado, Chiba 285-8668, Sakura, Japan; nobuyuki-kawasaki@ma.dic.co.jp

5 National Institute for Environmental Studies, 16-2 Onogawa, Tsukuba 305-8506, Ibaraki, Japan; kkomatsu@nies.go.jp

6 Faculty of Education \& Graduate School of Engineering, Soka University, 1-236 Tangi-Machi, Hachioji-Shi 192-8577, Tokyo, Japan; victor@soka.ac.jp

* Correspondence: shuhaila@unisel.edu.my; Tel.: +60-355-223-428

\begin{abstract}
The assessment of water-extractable organic matter using an autoclave can provide useful information on physical, chemical, and biological changes within the soil. The present study used virgin forest soils from Chini Forest Reserve, Langkawi Island, and Kenyir Forest Reserve (Malaysia), extracted using different extraction methods. The dissolved organic carbon (DOC), total dissolved nitrogen (TDN), total dissolved phosphorus (TDP), and ammonium-nitrate content were higher in the autoclave treatments, up to 3.0,1.3, 1.2, and 1.4 times more than by natural extraction (extracted for $24 \mathrm{~h}$ at room temperature). Overall, the highest extractable DOC, TDN, TDP, ammonium and nitrate could be seen under autoclaved conditions $121^{\circ} \mathrm{C} 2 \times$, up to $146.74 \mathrm{mg} \mathrm{C} / \mathrm{L}, 8.97 \mathrm{mg} \mathrm{N} / \mathrm{L}$, $0.23 \mathrm{mg} \mathrm{P} / \mathrm{L}, 5.43 \mathrm{mg} \mathrm{N} \mathrm{mg/L}$ and $3.47 \mathrm{~N} \mathrm{mg} / \mathrm{L}$, respectively. The soil extracts became slightly acidic with a higher temperature and longer duration. Similar trends were observed in the humic and nonhumic substances, where different types of soil extract treatments influenced the concentrations of the fractions. Different soil extraction methods can provide further details, thus widening the application of soil extracts, especially in microbes.
\end{abstract}

Keywords: autoclaved; dissolved organic carbon; fractions; humic substances; soil extraction; total dissolved nitrogen; total dissolved phosphorus

\section{Introduction}

Dissolved organic matter (DOM) is ubiquitous in aquatic environments and plays a critical role in the interplay between the hydrosphere, biosphere, and atmosphere [1] Water is the standard and most widely used solvent, and water-extractable organic matter is considered a readily available substrate in soil extraction for the preparation of enriched soil-media for algae cultivation [2,3]. Even though the extraction comprised only $<2 \%$ of the total soil organic matter, the process signified important roles in many chemical and biological processes in topsoil and subsoil [4]. Soil organic matter (SOM) is the largest carbon pool in the terrestrial ecosystem [5]. SOM can exist in different forms of fractions as 
simple as amino acids and monomeric acids to complex molecules such as protein, lignin, cellulose, and it all comes together with decomposed and partially decomposed plant and microbial residues [6]. Numerous studies have focused on carbon cycle modelling to improve the understanding of carbon stabilization in soils $[5,7,8]$.

The organic component of soil can be divided into SOM and DOM. DOM is identified to include a broad spectrum of organic constituents with molecular weights ranging from hundreds to more than $300,000 \mathrm{Da}$ [9]. It represents a small but highly important fraction of the SOM carbon due to its high reactivity [10]. DOM is a mixture of various organic aromatic compounds derived from fulvic acids, lignin, oligomeric and monomeric sugar derivatives, amino acids, and fatty acids between $\mathrm{C} 14$ and $\mathrm{C} 54$ originating from plant and dead bacteria $[4,11]$. Two major types of DOM can be identified as nonhumic and humic substances. Nonhumic substances are the compounds of well-described classes such as amino acids, lipids, proteins, waxes, and carbohydrates [12]. Humic substances are supramolecular (a complex of molecules), rich in oxygen-containing functional groups, commonly $\mathrm{COOH}$, phenolic and enolic $\mathrm{OH}$, alcoholic $\mathrm{OH}$, and $\mathrm{C}=\mathrm{O}$ of quinones [13]. However, DOM and DOC are used differently when the dissolved fraction of organic matter is used. DOM can be defined as the entire organic molecule, while DOC is only specific to the carbon fraction. Since DOM is difficult to quantify, carbon measurements are preferred [14]. However, DOM can be assumed as $45-50 \%$ organic carbon by mass [15]. The presence of humic substances greatly influences the natural organic material, as they are very soluble and provide complex groups such as carboxylic and phenolic hydroxyls [16]. They form stable complex compounds and act as carriers for toxic metals, vital for the bioavailability and mobility of metals in soil, sediment, and aquatic systems.

Besides water, commonly used solvents are $\mathrm{NaOH}, \mathrm{Na}_{4} \mathrm{P}_{2} \mathrm{O}_{7}, \mathrm{EDA}$ (ethylenediamine), DMSO (dimethylsulfoxide), and other organic solvents that can dissolve insoluble organic matter under natural condition [17]. However, these solvents contribute to the alteration of the chemical characteristics of the extracted DOM. NaOH and $\mathrm{Na}_{4} \mathrm{P}_{2} \mathrm{O}_{7}$ stimulate the oxidation process, while EDA enriches the recovery nutrients with nitrogen [18]. Thus, water, a natural solvent, should be used to limit the chemical alteration of extracted SOM [19]. However, water is less efficient than other solvents in extracting a high amount of DOM because the complex humus hinders the ability of water to solubilize soil nutrients. Previous research has demonstrated a wide range of extraction temperatures $\left(20^{\circ} \mathrm{C}\right.$ to $100{ }^{\circ} \mathrm{C}$ ), with extraction times from $1 \mathrm{~h}$ to $24 \mathrm{~h}$ [19]. However, the possibility of aqueous soil extraction methods using an autoclave has been overlooked. Hence, the purpose of our study was to evaluate the effect of elevated temperature and extraction times on the chemical composition of organic matter in water extraction. This study focuses on the concentrations of hydrophobic and hydrophilic fractions of soil organic matter using the designated extraction methods.

\section{Results}

\subsection{Physicochemical Analysis of Soils}

The physicochemical analysis of soils is recorded in Tables 1 and 2. All soils are distinguished as acidic (low $\mathrm{pH}$ ranging from 3.97 to 4.83). The texture of Chini lake and Kenyir soils are composed of silt (94.89-94.91\%), sand (4.47-4.57\%), and clay (0.52-0.63\%). Meanwhile, the Langkawi Island soil is mainly composed of sand $(95.00 \%)$, silt $(0.00 \%)$, and clay $(4.00 \%)$. The obvious physical observation can be made based on the soil color, where Chini was dark brown, while Kenyir and Langkawi Island soils were light yellowish-brown. The color of soils can be an indicator of the availability of organic matter content in the soil.

The chemical contents in the soil are listed in Table 2. Chini soil exhibited the highest concentrations of organic matter in most parameters, i.e., soil organic carbon (SOC), nitrogen $(\mathrm{N})$, and phosphorus $(\mathrm{P})$ as $1.03-55.78 \%, 0.11-0.41 \%$, and $1.62-24.23 \%$. Meanwhile, no significant differences $(p<0.05)$ are noted in the Langkawi and Kenyir soils in terms of total carbon $(\mathrm{C}), \mathrm{N}$, and $\mathrm{P}$ content. The heavy metal results vary, and some parameters could not be determined due to the very low (out of range) concentrations. The level of iron (Fe) 
ranged from 755.47 to $771.98 \mathrm{mg} / \mathrm{kg}$, with no significant difference $(p<0.05)$ between the soils. Kenyir soil recorded very high concentrations of lead $(\mathrm{Pb})$, cadmium $(\mathrm{Cd})$, and zinc (Zn) at 33.83, 0.27, and $27.09 \mathrm{mg} / \mathrm{kg}$ but the levels of arsenic (As), mercury ( $\mathrm{Hg})$, and silver (Ag) cannot be determined due to concentrations fall below range of measurement.

Table 1. Physical properties of soils.

\begin{tabular}{cccc}
\hline Soil Sample & Chini Lake & Langkawi Island & Kenyir Lake \\
\hline $\mathrm{pH}$ & $3.97 \pm 0.03^{\mathrm{a}}$ & $4.23 \pm 0.03^{\mathrm{b}}$ & $4.83 \pm 0.03^{\mathrm{c}}$ \\
Sand (\%) & $4.47 \pm 0.06^{\mathrm{a}}$ & $95 \pm 0.00^{\mathrm{b}}$ & $4.57 \pm 0.00^{\mathrm{a}}$ \\
Silt (\%) & $94.89 \pm 0.06^{\mathrm{a}}$ & $0.00 \pm 0.00 \mathrm{~b}$ & $94.91 \pm 0.00^{\mathrm{a}}$ \\
Clay (\%) & $0.63 \pm 0.01^{\mathrm{a}}$ & $4.00 \pm 0.00^{\mathrm{b}}$ & $0.52 \pm 0.00^{\mathrm{c}}$ \\
Soil type & Silt loam & Sandy loam & Silt loam \\
Color & Dark brown & Light yellowish brown & Light yellowish brown \\
\hline
\end{tabular}

The value shows as mean value with $(n=3)$ followed by standard deviation, \pm . ${ }^{\mathrm{a}, \mathrm{b}, \mathrm{c}}$ within rows, mean values followed by the same letter are not significantly different according to one-way ANOVA $(p>0.05)$ and Tukey post hoc.

Table 2. Chemical Analysis of soils.

\begin{tabular}{cccc}
\hline Soil Location & Chini Lake & Langkawi Island & Kenyir Lake \\
\hline Total Organic Carbon (\%) & $55.78 \pm 1.29^{\mathrm{a}}$ & $2.34 \pm 0.02^{\mathrm{b}}$ & $1.03 \pm 0.02^{\mathrm{b}}$ \\
Nitrogen (\%) & $0.41 \pm 0.05^{\mathrm{a}}$ & $0.17 \pm 0.00^{\mathrm{b}}$ & $0.17 \pm 0.00^{\mathrm{b}}$ \\
Phosphorus (\%) & $24.23 \pm 0.84^{\mathrm{a}}$ & $2.27 \pm 0.01^{\mathrm{b}}$ & $1.62 \pm 0.01^{\mathrm{b}}$ \\
\hline Trace Metals (mg/kg) & & & \\
\hline Iron & $755.47 \pm 16.15^{\mathrm{a}}$ & $767.09 \pm 1.57^{\mathrm{a}}$ & $771.98 \pm 2.21^{\mathrm{a}}$ \\
Arsenic & $\mathrm{ND}<1$ & $\mathrm{ND}<1$ & $\mathrm{ND}<1^{\mathrm{a}}$ \\
Cadmium & $0.20 \pm 0.03^{\mathrm{a}}$ & $0.25 \pm 0.03^{\mathrm{a}}$ & $0.27 \pm 0.08^{\mathrm{a}}$ \\
Chromium & $34.45 \pm 3.92$ & $\mathrm{ND}<2^{\mathrm{N}}$ & $\mathrm{ND}<2^{\mathrm{N}}$ \\
Chromium VII & $2.98 \pm 0.18$ & $\mathrm{ND}<3$ & $\mathrm{ND}<3$ \\
Lead & $3.06 \pm 0.31^{\mathrm{a}}$ & $3.52 \pm 0.23^{\mathrm{a}}$ & $33.83 \pm 1.90^{\mathrm{b}}$ \\
Copper & $5.26 \pm 0.43^{\mathrm{a}}$ & $1.23 \pm 0.08^{\mathrm{b}}$ & $1.65 \pm 0.03^{\mathrm{b}}$ \\
Nickel & $5.50 \pm 0.33^{\mathrm{a}}$ & $8.98 \pm 0.54^{\mathrm{b}}$ & $5.42 \mathrm{a} \pm 0.29^{\mathrm{a}}$ \\
Zinc & $5.67 \pm 1.05^{\mathrm{a}}$ & $8.56 \pm 0.45^{\mathrm{b}}$ & $27.09 \pm 1.07^{\mathrm{c}}$ \\
Mercury & $\mathrm{ND}<1$ & $\mathrm{ND}<1$ & $\mathrm{ND}<1$ \\
Silver & $\mathrm{ND}<10^{\mathrm{N}}$ & $\mathrm{ND}<10$ & $\mathrm{ND}<10$ \\
\hline
\end{tabular}

$\mathrm{ND}=$ not determined; ${ }^{\mathrm{a}, \mathrm{b}, \mathrm{c}}$ within rows, mean values followed by same letter are not significantly different according to one-way ANOVA $(p>0.05)$ and Tukey post hoc.

\subsection{Chemical Characterization of Different Aqueous Soil Extraction Methods}

Table 3 summarizes the results of selected chemical parameters using five different extraction methods. In general, autoclaved soil extracts always showed higher extractable nutrients than for $24 \mathrm{~h}$ room temperature extraction $(p<0.05)$. The percentage of DOC extracted using autoclaved temperature, $105{ }^{\circ} \mathrm{C} 1 \times$, ranged from $195.67 \%$ to $331.85 \%$. In comparison, the autoclaved extract at $121^{\circ} \mathrm{C} 1 \times$ exhibited a significantly higher percentage (414.94-669.44\%) than at $105^{\circ} \mathrm{C} 1 \times$. Total dissolved nitrogen (TDN) also showed a similar trend, where the autoclaved temperature at $121^{\circ} \mathrm{C} 1 \times$ always yielded a higher percentage of nitrogen $(89.52-161.30 \%)$, which was significantly different to the autoclaved temperature at $105{ }^{\circ} \mathrm{C} 1 \times(31.88-114.57 \%)$. Extractable total dissolved phosphorus (TDP) was also significantly higher when autoclaved at $121{ }^{\circ} \mathrm{C} 1 \times(46.88-1800 \%)$ than at $105{ }^{\circ} \mathrm{C} 1 \times$ (40.63-1175\%). Similarly, the ammonia content showed the highest percentage, ranging from $98.10-204.15 \%$ when autoclaved at $121{ }^{\circ} \mathrm{C} 1 \times$ than at $105{ }^{\circ} \mathrm{C} 1 \times$, ranging from $35.24-84.33 \%$, which was significantly lower $(p<0.05)$.

Another approach to aqueous extractable organic matter of soil focuses on autoclave duration at different temperatures, $105^{\circ} \mathrm{C}$ and $121^{\circ} \mathrm{C}$. Prolonging the autoclave process duration from $1 \mathrm{~h}$ to $2 \mathrm{~h}$ increased the amount of extractable nutrient slightly, whereby an enhanced extractable percentage of DOC (21.70-37.76\%) was noted (Table 3). The results 
indicate that prolonged autoclave duration from $1 \mathrm{~h}$ to $2 \mathrm{~h}$ did not significantly increase or decrease the TDN, except for autoclaved Chini lake soil at $121^{\circ} \mathrm{C}$. The extractable amount of TDP significantly increased upon the prolonged duration of the autoclave process at $121{ }^{\circ} \mathrm{C}(41.73-44.68 \%)$, except for Langkawi soil, where both autoclave temperatures did not enhance extractable TDP. Next, autoclaving at $121^{\circ} \mathrm{C}$ showed a significant increase in three soil samples ranging from $20.7-81.73 \%$. Autoclaving at $105^{\circ} \mathrm{C}$ did not show any significant enhancement except for the Chini soil, which showed a percentage increase of about $34.50 \%$. Meanwhile, the Chini and Langkawi soils showed a significant increase at $105{ }^{\circ} \mathrm{C}$ and $121{ }^{\circ} \mathrm{C}(37.58-41.17 \%)$ for nitrate, but not in the Kenyir soil.

Table 3. Selected chemical analysis of soil extracts using various extraction methods.

\begin{tabular}{|c|c|c|c|c|c|c|}
\hline Site & Treatments & $\begin{array}{c}\text { Dissolved } \\
\text { Organic Carbon, } \\
\mathrm{C}(\mathrm{mg} / \mathrm{L})\end{array}$ & $\begin{array}{c}\text { Total Dissolved } \\
\text { Nitrogen, } \\
\text { N (mg/L) }\end{array}$ & $\begin{array}{c}\text { Total Dissolved } \\
\text { Phosphorus, } \\
\mathrm{PO}_{4}(\mathrm{mg} / \mathrm{L})\end{array}$ & $\begin{array}{c}\text { Ammonia } \\
\text { Concentrations, } \\
\mathrm{NH}_{3}(\mathrm{mg} / \mathrm{L})\end{array}$ & $\begin{array}{c}\text { Nitrate, } \\
\mathrm{NO}_{3}-(\mathrm{mg} / \mathrm{L})\end{array}$ \\
\hline \multirow{5}{*}{$\begin{array}{c}\text { Chini Forest } \\
\text { Reserve }\end{array}$} & $24 \mathrm{~h}$ & $74.15 \pm 5.21^{a}$ & $6.63 \pm 0.3^{a}$ & $0.20 \pm 0.03^{a}$ & $3.50 \pm 0.53^{\mathrm{a}}$ & $0.67 \pm 0.58^{a}$ \\
\hline & $105^{\circ} \mathrm{C} 1 \times$ & $303.22 \pm 17.19^{b}$ & $14.23 \pm 1.65^{b}$ & $0.67 \pm 0.3^{b}$ & $4.73 \pm 0.12^{b}$ & $3.40 \pm 0.61^{b}$ \\
\hline & $105^{\circ} \mathrm{C} 2 \times$ & $404.48 \pm 24.11^{\mathrm{c}}$ & $12.80 \pm 1.9^{b}$ & $0.73 \pm 0.2^{b}$ & $6.37 \pm 0.21^{c}$ & $4.73 \pm 0.40^{\mathrm{c}}$ \\
\hline & $121^{\circ} \mathrm{C} 1 \times$ & $503.11 \pm 39.99^{d}$ & $17.33 \pm 2.0^{b}$ & $1.04 \pm 0.06^{\mathrm{c}}$ & $6.93 \pm 1.01^{\mathrm{d}}$ & $5.50 \pm 0.78^{\mathrm{d}}$ \\
\hline & $121^{\circ} \mathrm{C} 2 \times$ & $677.95 \pm 69.10^{\mathrm{e}}$ & $23.47 \pm 4.0^{\mathrm{c}}$ & $1.47 \pm 0.17^{\mathrm{d}}$ & $12.60 \pm 0.40^{\mathrm{e}}$ & $7.57 \pm 0.32^{\mathrm{e}}$ \\
\hline \multirow{5}{*}{$\begin{array}{l}\text { Langkawi } \\
\text { Island }\end{array}$} & $24 \mathrm{~h}$ & $19.92 \pm 1.26^{\mathrm{a}}$ & $5.33 \pm 1.89^{a}$ & $0.01 \pm 0.02^{\mathrm{a}}$ & $1.45 \pm 0.07^{\mathrm{a}}$ & NA \\
\hline & $105^{\circ} \mathrm{C} 1 \times$ & $86.03 \pm 4.62^{b}$ & $7.03 \pm 0.15^{\mathrm{a}}$ & $0.17 \pm 0.01^{b}$ & $2.67 \pm 0.23^{b}$ & $1.13 \pm 0.15^{\mathrm{a}}$ \\
\hline & $105^{\circ} \mathrm{C} 2 \times$ & $108.55 \pm 5.61^{\mathrm{c}}$ & $7.37 \pm 0.23^{\mathrm{a}}$ & $0.21 \pm 0.05^{b}$ & $3.00 \pm 0.20^{b}$ & $1.60 \pm 0.10^{b}$ \\
\hline & $121^{\circ} \mathrm{C} 1 \times$ & $153.27 \pm 6.44^{d}$ & $12.33 \pm 1.89^{b}$ & $0.25 \pm 0.03^{c}$ & $4.40 \pm 0.53^{c}$ & $1.67 \pm 0.31^{\mathrm{c}}$ \\
\hline & $121{ }^{\circ} \mathrm{C} 2 \times$ & $206.55 \pm 3.23^{\mathrm{e}}$ & $13.93 \pm 2.16^{b}$ & $0.27 \pm 0.03^{c}$ & $6.47 \pm 0.12^{\mathrm{d}}$ & $2.30 \pm 0.44^{\mathrm{d}}$ \\
\hline \multirow{5}{*}{$\begin{array}{c}\text { Sah Kecil } \\
\text { Island (Kenyir) }\end{array}$} & $24 \mathrm{~h}$ & $22.80 \pm 1.25^{\mathrm{a}}$ & $4.13 \pm 1.32^{\mathrm{a}}$ & $0.11 \pm 0.01^{\mathrm{a}}$ & $2.23 \pm 0.21^{\mathrm{a}}$ & $1.43 \pm 0.12^{\mathrm{a}}$ \\
\hline & $105^{\circ} \mathrm{C} 1 \times$ & $67.40 \pm 8.97^{b}$ & $6.30 \pm 0.82^{b}$ & $0.13 \pm 0.03^{b}$ & $3.43 \pm 0.35^{b}$ & $2.57 \pm 0.15^{b}$ \\
\hline & $105^{\circ} \mathrm{C} 2 \times$ & $92.84 \pm 27.23^{b}$ & $7.83 \pm 1.12^{b}$ & $0.16 \pm 0.03^{b}$ & $3.87 \pm 0.21^{b}$ & $2.77 \pm 0.15^{b}$ \\
\hline & $121{ }^{\circ} \mathrm{C} 1 \times$ & $117.38 \pm 3.25^{c}$ & $6.03 \pm 1.08^{b}$ & $0.13 \pm 0.01^{\mathrm{c}}$ & $4.50 \pm 0.30^{c}$ & $3.23 \pm 0.31^{c}$ \\
\hline & $121^{\circ} \mathrm{C} 2 \times$ & $146.74 \pm 4.00^{\mathrm{d}}$ & $8.97 \pm 0.55^{b}$ & $0.23 \pm 0.03^{d}$ & $5.43 \pm 0.47^{\mathrm{d}}$ & $3.47 \pm 0.15^{\mathrm{c}}$ \\
\hline
\end{tabular}

The values shown as mean with $(n=3)$ followed by \pm (standard deviation); NA = not available; , a, ,c,d,e within column, same alphabets indicated no significant difference between treatments within same group using one-way ANOVA $(p>0.05)$ and Tukey post hoc. Comparison between treatments; $\left(24 \mathrm{~h}-105^{\circ} \mathrm{C} 1 \times, 24 \mathrm{~h}-21^{\circ} \mathrm{C} 1 \times, 105^{\circ} \mathrm{C} 1 \times-105^{\circ} \mathrm{C} 2 \times\right.$ and $\left.121^{\circ} \mathrm{C} 1 \times-121^{\circ} \mathrm{C} 2 \times\right)$.

Concentrations of total $\mathrm{N}$ in soil extracts were dominated by ammonia $\left(\mathrm{NH}_{3}\right)$ in all soil samples (Figure 1). $\mathrm{NH}_{3}$ contributed to $27 \%$ to $54 \%$ and $33 \%$ to $74 \%$ of total $\mathrm{N}$ for natural extractions and autoclaved extractions, respectively. Nitrate concentrations contributed to about $10 \%$ to $34 \%$ of total $\mathrm{N}$ for natural extractions. Meanwhile, the nitrate amount for autoclaved extraction increased to some extent, i.e., from $16 \%$ to $54 \%$ of total N.

Figure 2 shows the significant difference of in the $\mathrm{pH}$ of the soil using natural extraction compared to the autoclave extraction, except for Langkawi soil, where the $\mathrm{pH}$ changes were unnoticeable. When autoclaved, the soil extract became more acidic (lower $\mathrm{pH}$ value). Although increasing the autoclave duration from $1 \mathrm{~h}$ to $2 \mathrm{~h}$ decreased the $\mathrm{pH}$ value slightly, the value was too small to notice.

In general, the autoclaved extracts always showed a higher amount of extractable DOM than the $24 \mathrm{~h}$ incubation at room temperature. Moreover, autoclaving at $121{ }^{\circ} \mathrm{C}$ exhibited the highest range of DOM achieved. The prolonged autoclave duration of aqueous soil extracts at $121^{\circ} \mathrm{C} 2 \times$ achieved the highest amount of extractable DOM than other treatments, although the trend indicated various patterns among the soils tested. 


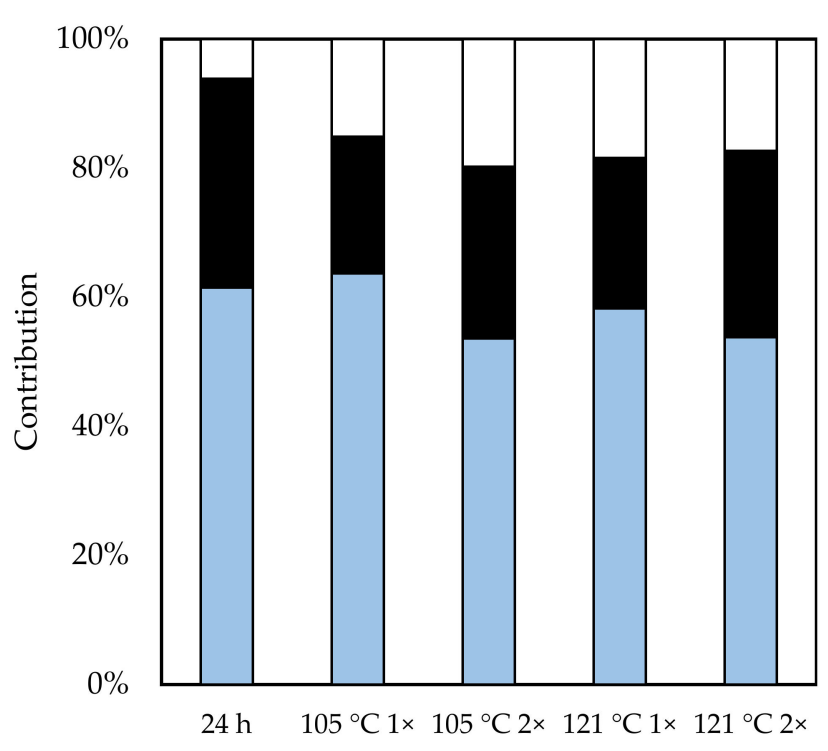

$\square$ Total $\mathrm{N} \square$ Ammonia $\left(\mathrm{NH}_{3}\right) \square$ Nitrate $\left(\mathrm{NO}_{3}{ }^{-}\right)$

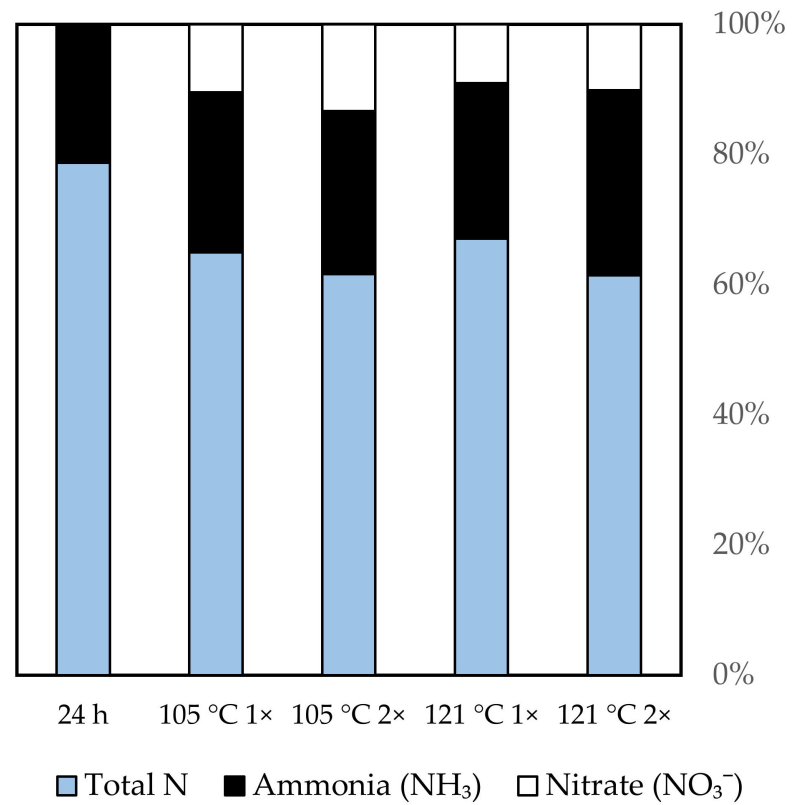

(b)

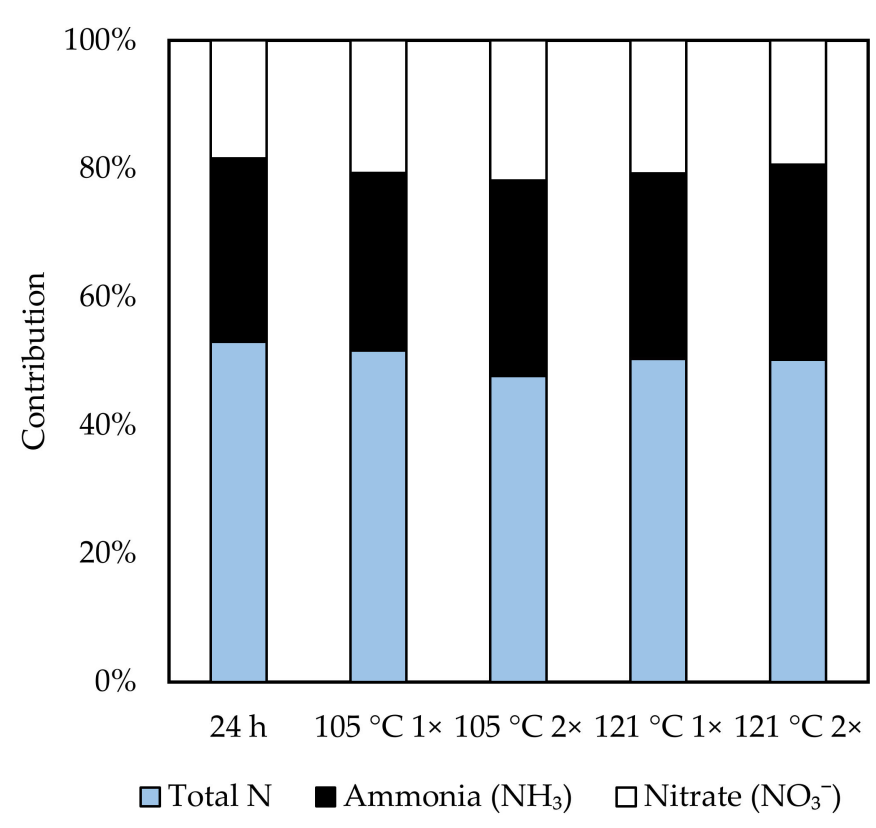

(c)

Figure 1. Total contribution of ammonia, $\mathrm{NH}_{4}{ }^{+}$and nitrate, $\mathrm{NO}_{3}$ to total organic $\mathrm{N}$ for (a) Chini Forest Reserve (b) Langkawi Island and (c) Kenyir soil, respectively. Bars represent average value of concentrations at $(n=3)$. 


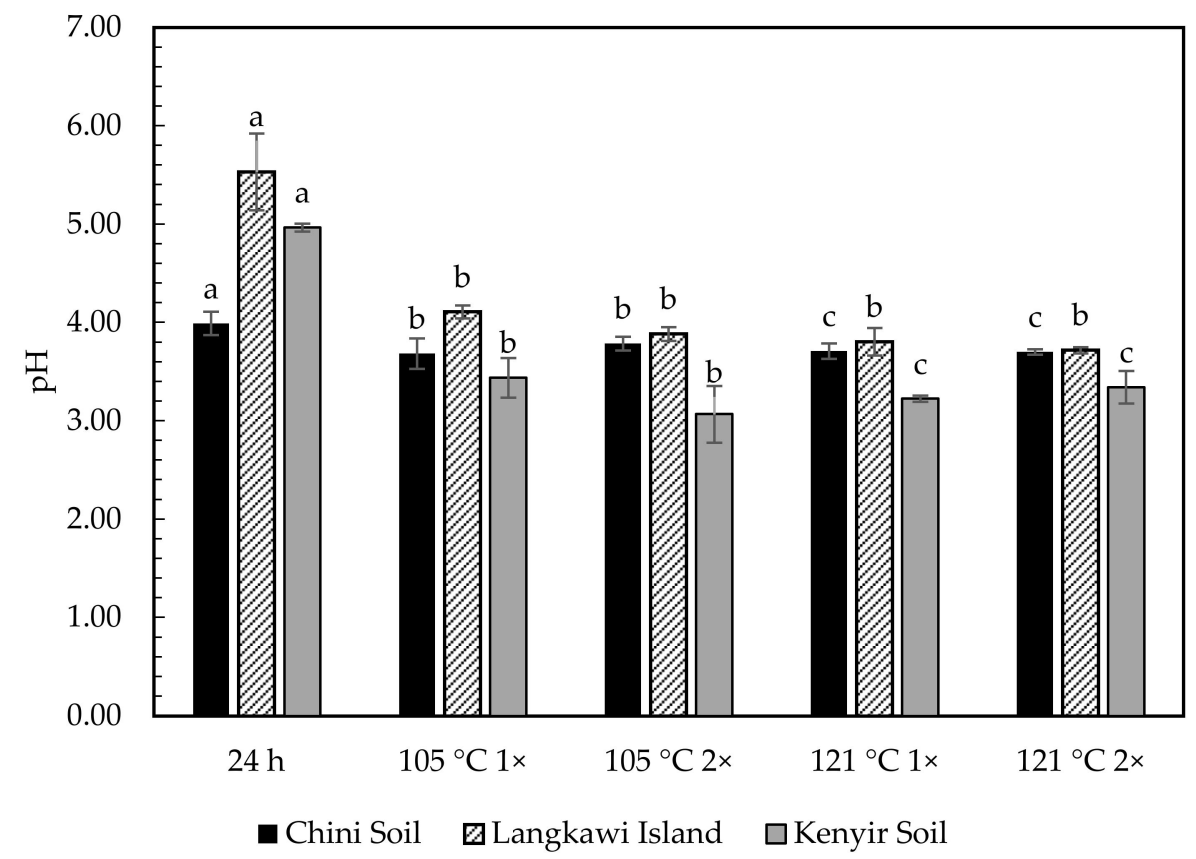

Figure 2. The $\mathrm{pH}$ of different extraction methods. Bars on the graph represent the standard error at $n=3$. ${ }^{\mathrm{a}, \mathrm{b}, \mathrm{c}}$ Same letter on top of graph indicated significant difference using one-way ANOVA $(p>0.05)$ and Tukey post hoc. Comparison between treatments; $\left(24 \mathrm{~h}-105^{\circ} \mathrm{C} 1 \times, 24 \mathrm{~h}-121^{\circ} \mathrm{C} 1 \times\right.$, $105^{\circ} \mathrm{C} 1 \times-105^{\circ} \mathrm{C} 2 \times$ and $\left.121^{\circ} \mathrm{C} 1 \times-121^{\circ} \mathrm{C} 2 \times\right)$.

\subsection{Hydrophobic and Hydrophilic Fraction}

Table 4 and Figures $3-5$ show the chemical characterization of the soil extract fractions. In general, the hydrophilic fraction $(\mathrm{HiF})$ dominated in all soil extract treatments, with the percentage accounting for more than $54 \%$ of their DOM as DOC. Humic substances (HS) were the second most abundant fraction, ranging from about 23-32\%. All treatments of soil extracts were mainly in acidic conditions. Meanwhile, the hydrophobic neutral fraction $(\mathrm{HoN})$ was considered very low $(0-6 \%)$ of the total DOM. The HoN value greatly declined in number $(74 \%$ to $100 \%$ ) upon prolonged autoclave duration. Overall, Chini soil contained the highest $\mathrm{HS}$ and $\mathrm{HiF}$ fractions, averaging between 19.86-200.25 mg C/L and 57.08-506.69 $\mathrm{mg} \mathrm{C} / \mathrm{L}$. In contrast, the $\mathrm{HS}$ and HiF soil fractions for Langkawi ranged between $45.63-60.79 \mathrm{mg} \mathrm{C} / \mathrm{L}$ and $66.27-150.13 \mathrm{mg} \mathrm{C} / \mathrm{L}$. The Kenyir DOM fraction indicated the lowest range from 10.43 to $33.57 \mathrm{mg} \mathrm{C} / \mathrm{L}$ for $\mathrm{HS}$ and 31.2 to $109.20 \mathrm{mg} \mathrm{C} / \mathrm{L}$ for $\mathrm{HiF}$.

The extractable fraction DOM at room temperature showed a lower range of HS and $\mathrm{HiF}$ fractions, ranging from $10.43-19.86 \mathrm{mg} \mathrm{C} / \mathrm{L}$ and $31.25-57.08 \mathrm{mg} \mathrm{C} / \mathrm{L}$. Meanwhile, both autoclave temperatures $\left(105^{\circ} \mathrm{C}\right.$ and $\left.121^{\circ} \mathrm{C}\right)$ showed increasing DOM fractions in DOC, i.e., about $83-588 \%$ and $3-530 \%$ for $\mathrm{HS}$ and HiF. The autoclave temperature at $121{ }^{\circ} \mathrm{C}$ indicated a higher DOM fraction content, i.e., 1.4-2.4 times higher than $105{ }^{\circ} \mathrm{C}$. The prolonged autoclave duration from $1 \mathrm{~h}$ to $2 \mathrm{~h}$ exhibited a greater increment for both $\mathrm{HS}$ and $\mathrm{HiF}$ fractions. The autoclave temperature of $105^{\circ} \mathrm{C}$ denotes the increased percentage of about $37-55 \%$ for HS fraction and $30-128 \%$ for HiF. Apart from that, $121^{\circ} \mathrm{C} 2 \times$ always showed the highest DOM fractions, with increased percentage (15-46\% for $\mathrm{H}$ and $37-45 \%$ for $\mathrm{HiF}$ ), except for HoN. 
Table 4. Chemical characterization of dissolved organic matter fractions.

\begin{tabular}{|c|c|c|c|c|c|}
\hline Site & Treatments & $\begin{array}{c}\text { Total } \\
\text { DOC (mg C/L) }\end{array}$ & $\begin{array}{c}\text { Hydrophobic } \\
\text { Fractions (mg C/L) }\end{array}$ & $\begin{array}{c}\text { Hydrophobic } \\
\text { Neutrals (mg C/L) }\end{array}$ & $\begin{array}{c}\text { Hydrophilic } \\
\text { Fractions (mg C/L) }\end{array}$ \\
\hline \multirow[t]{5}{*}{ Chini } & $24 \mathrm{~h}$ & $82.54 \pm 11.16^{a}$ & $19.86 \pm 7.40^{\mathrm{a}}$ & $5.61 \pm 8.09^{\mathrm{a}}$ & $57.08 \pm 15.07^{\mathrm{a}}$ \\
\hline & $105^{\circ} \mathrm{C} 1 \times$ & $343.69 \pm 23.81^{b}$ & $80.38 \pm 14.28^{b}$ & $14.34 \pm 24.69^{b}$ & $248.95 \pm 4.21^{\mathrm{b}}$ \\
\hline & $105^{\circ} \mathrm{C} 2 \times$ & $444.95 \pm 9.90^{\mathrm{c}}$ & $125.19 \pm 13.20^{c}$ & $0.86 \pm 1.49^{c}$ & $325.54 \pm 25.07^{c}$ \\
\hline & $121^{\circ} \mathrm{C} 1 \times$ & $525.83 \pm 14.10^{d}$ & $136.84 \pm 10.23^{d}$ & $29.33 \pm 6.34^{d}$ & $359.66 \pm 25.04^{d}$ \\
\hline & $121^{\circ} \mathrm{C} 2 \times$ & $715.32 \pm 31.60^{\mathrm{e}}$ & $200.25 \pm 0.76^{\mathrm{e}}$ & $8.48 \pm 11.92^{\mathrm{e}}$ & $506.69 \pm 29.80^{e}$ \\
\hline \multirow[t]{5}{*}{ Langkawi } & $24 \mathrm{~h}$ & $19.53 \pm 1.23^{a}$ & $13.90 \pm 1.30^{\mathrm{a}}$ & $1.06 \pm 0.93^{\mathrm{a}}$ & $5.36 \pm 1.98^{a}$ \\
\hline & $105^{\circ} \mathrm{C} 1 \times$ & $84.94 \pm 6.66^{b}$ & $33.24 \pm 7.93^{b}$ & $8.81 \pm 10.93^{\mathrm{a}}$ & $47.64 \pm 20.68^{b}$ \\
\hline & $105^{\circ} \mathrm{C} 2 \times$ & $101.70 \pm 14.10^{b}$ & $45.63 \pm 9.13^{c}$ & $0.16 \pm 0.27^{a}$ & $66.27 \pm 7.19^{b}$ \\
\hline & $121^{\circ} \mathrm{C} 1 \times$ & $151.55 \pm 18.51^{c}$ & $50.91 \pm 4.55^{\mathrm{d}}$ & $7.21 \pm 12.49^{\mathrm{a}}$ & $104.03 \pm 34.93^{c}$ \\
\hline & $121^{\circ} \mathrm{C} 2 \times$ & $210.93 \pm 11.18^{d}$ & $60.79 \pm 2.48^{d}$ & $0.89 \pm 0.99^{a}$ & $150.13 \pm 13.28^{d}$ \\
\hline \multirow[t]{5}{*}{ Kenyir } & $24 \mathrm{~h}$ & $42.23 \pm 0.90^{\mathrm{a}}$ & $10.43 \pm 2.25^{\mathrm{a}}$ & $1.17 \pm 1.16^{\mathrm{a}}$ & $31.25 \pm 4.40^{\mathrm{a}}$ \\
\hline & $105^{\circ} \mathrm{C} 1 \times$ & $59.81 \pm 19.18^{a}$ & $19.18 \pm 3.32^{\mathrm{a}}$ & $8.33 \pm 6.03^{b}$ & $32.30 \pm 5.02^{a}$ \\
\hline & $105^{\circ} \mathrm{C} 2 \times$ & $93.60 \pm 43.62^{\mathrm{a}}$ & $26.44 \pm 11.33^{\mathrm{a}}$ & $0.00 \pm 0.00^{\mathrm{c}}$ & $73.70 \pm 31.78^{b}$ \\
\hline & $121^{\circ} \mathrm{C} 1 \times$ & $105.21 \pm 3.80^{b}$ & $29.07 \pm 0.77^{b}$ & $0.00 \pm 0.12^{d}$ & $79.49 \pm 6.96^{c}$ \\
\hline & $121^{\circ} \mathrm{C} 2 \times$ & $135.18 \pm 1.08^{b}$ & $33.57 \pm 1.70^{b}$ & $0.00 \pm 0.00^{\mathrm{d}}$ & $109.20 \pm 3.0^{d}$ \\
\hline
\end{tabular}

The values shown as mean with $(n=3)$ followed by \pm (standard deviation). ${ }^{a, b, c, d, e}$ within row, same low letter case indicated no significant difference between treatments within same group using one-way ANOVA $(p>0.05)$. Comparison between treatments; $\left(24 \mathrm{~h}-105^{\circ} \mathrm{C} 1 \times\right.$, $24 \mathrm{~h}-121^{\circ} \mathrm{C} 1 \times, 105^{\circ} \mathrm{C} 1 \times-105^{\circ} \mathrm{C} 2 \times$ and $\left.121^{\circ} \mathrm{C} 1 \times-121^{\circ} \mathrm{C} 2 \times\right)$.

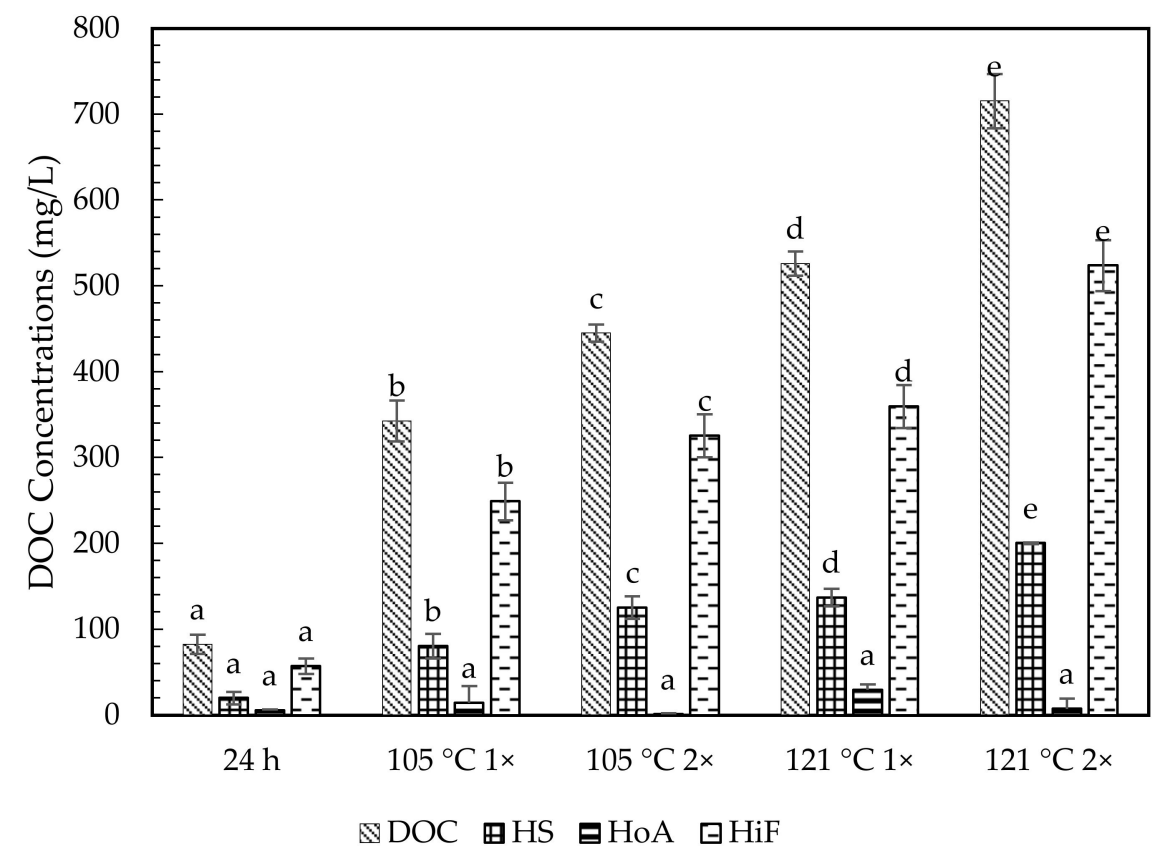

Figure 3. Fraction of dissolved organic matter for Chini soil extracts. DOM fractions are DOC, total dissolved organic carbon; HS, humic substances; HoA; hydrophobic neutral and HiF, hydrophilic fraction. Bars represent standard error with $n=3$. Same letter on top of graph indicated no significance difference using one-way ANOVA $(p>0.05)$ and Tukey post hoc. Comparison between treatments; $\left(24 \mathrm{~h}-105^{\circ} \mathrm{C} 1 \times, 24 \mathrm{~h}-121^{\circ} \mathrm{C} 1 \times, 105^{\circ} \mathrm{C} 1 \times-105^{\circ} \mathrm{C} 2 \times\right.$ and $\left.121^{\circ} \mathrm{C} 1 \times-121{ }^{\circ} \mathrm{C} 2 \times\right)$. 


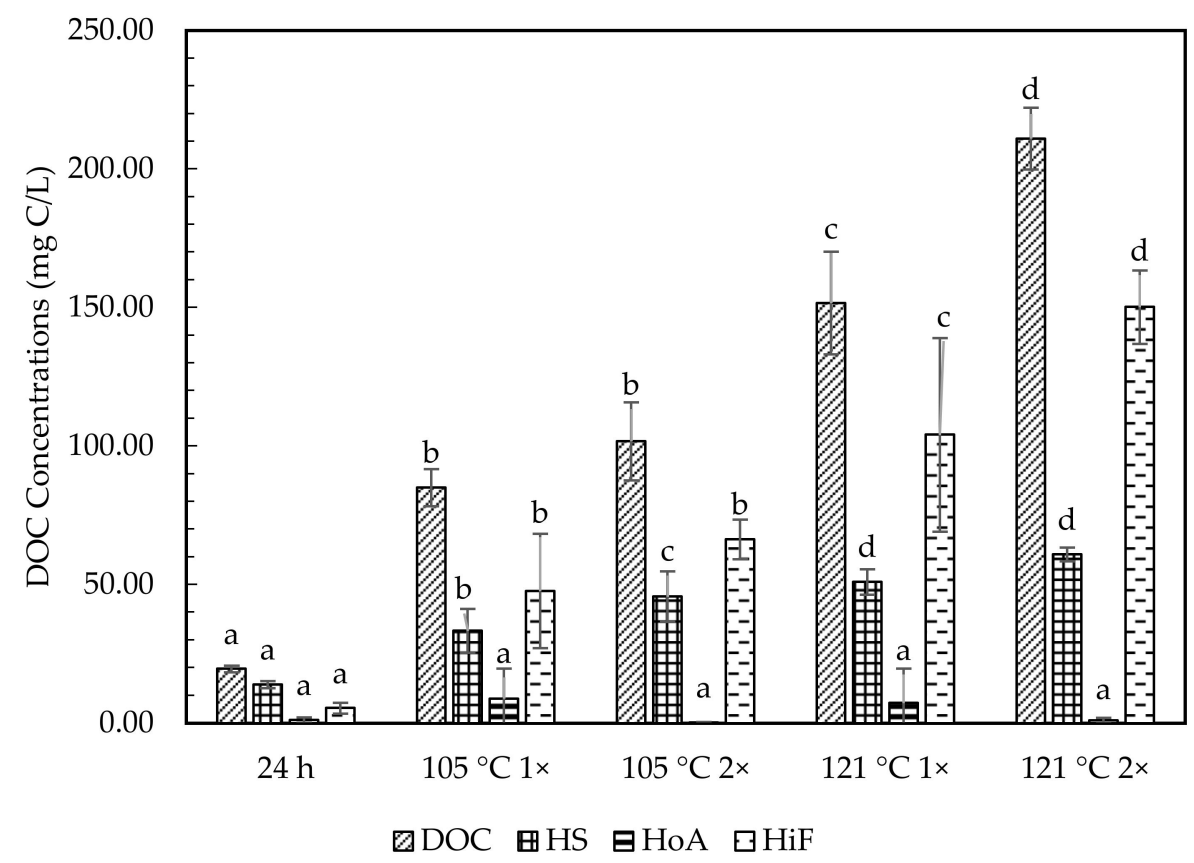

Figure 4. Fraction of dissolved organic matter for Langkawi soil extracts. DOM fractions are DOC, total dissolved organic carbon; HS, humic substances; HoA; hydrophobic neutral and HiF, hydrophilic fraction. Bar represents standard error at $n=3$. Same letter on top of graph indicated no significance difference using one-way ANOVA $(p>0.05)$ and Tukey post hoc. Comparison between treatments; $\left(24 \mathrm{~h}-105^{\circ} \mathrm{C} 1 \times, 24 \mathrm{~h}-121^{\circ} \mathrm{C} 1 \times, 105^{\circ} \mathrm{C} 1 \times-105^{\circ} \mathrm{C} 2 \times\right.$ and $\left.121^{\circ} \mathrm{C} 1 \times-121^{\circ} \mathrm{C} 2 \times\right)$.

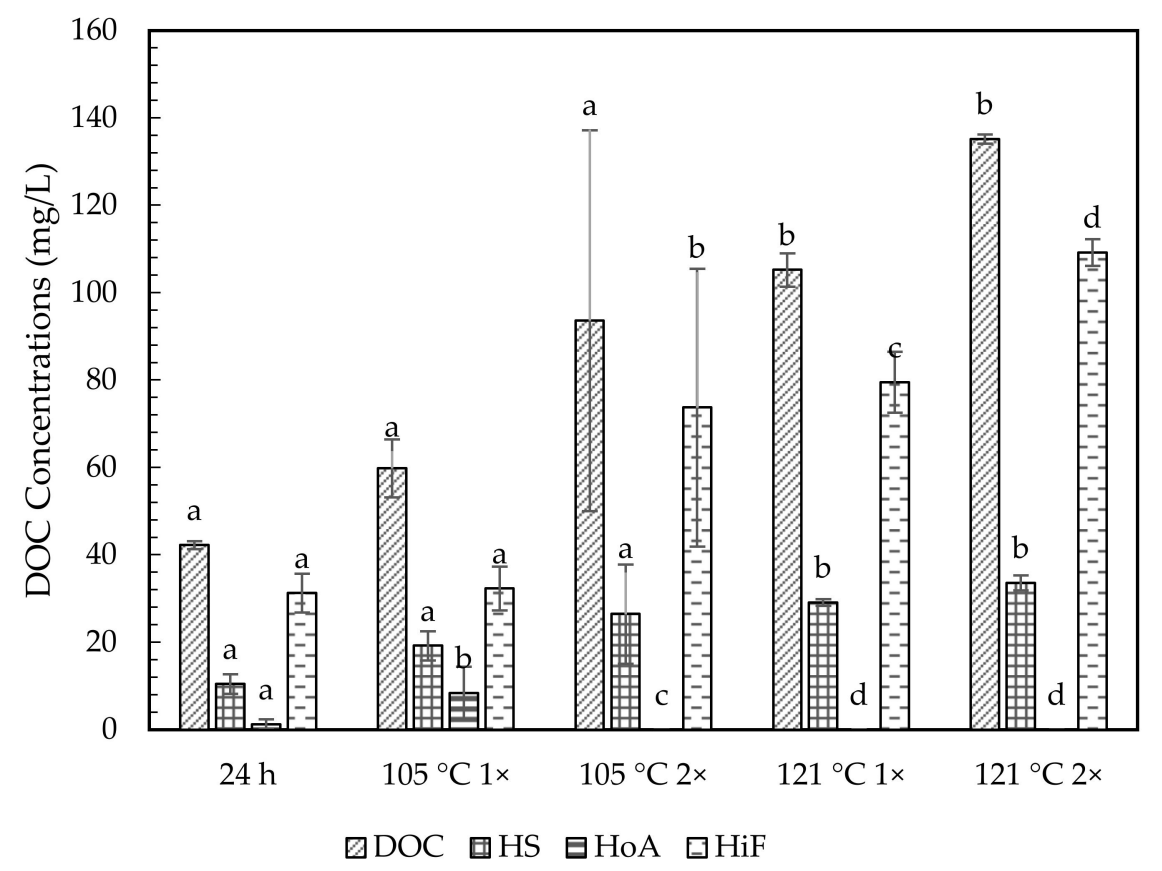

Figure 5. Fraction of dissolved organic matter for Kenyir soil extracts. DOM fractions are DOC, total dissolved organic carbon; HS, humic substances; HoA; hydrophobic neutral and HiF, hydrophilic fraction. Bars represent standard error with $n=3$. Same letters on top of graph indicate no significance difference using one-way ANOVA $(p>0.05)$ and Tukey post hoc. Comparison between treatments; $\left(24 \mathrm{~h}-105^{\circ} \mathrm{C} 1 \times, 24 \mathrm{~h}-121^{\circ} \mathrm{C} 1 \times, 105^{\circ} \mathrm{C} 1 \times-105^{\circ} \mathrm{C} 2 \times\right.$ and $\left.121^{\circ} \mathrm{C} 1 \times-121^{\circ} \mathrm{C} 2 \times\right)$. 


\section{Discussion}

\subsection{Physicochemical Analysis of Soils}

Based on the study by [20], the average $\mathrm{pH}$ of the three types of soil (inland, seasonal flood, and riverine) of the Chini forest ranged from 3.60 to $4.24,3.80$ to 4.37 , and 3.82 to 4.16. The $\mathrm{pH}$ indicated that most of the soils from their study were acidic, and it is very common due to weathering and the leaching process occurring within the soil. Other than that, the decomposition of organic matter due to biological process also contributed to the soil acidity [21].

The solubility, bioavailability, and mobility of trace elements are controlled by soil $\mathrm{pH}$; thus, affecting translocation in plants. Soil $\mathrm{pH}$ is also largely influenced by the partition of elements between the solid and liquid phases through precipitation-dissolution reactions [22]. It causes the mineral and organic soil fraction depending on the $\mathrm{pH}$ charges, where negative charges dominate in high $\mathrm{pH}$ and positive charges exist in low $\mathrm{pH}$. At low $\mathrm{pH}$, trace elements become soluble due to high desorption and low adsorption. This phenomenon could be explained by the competition between cation and the exuberance of $\mathrm{H}^{+}$ ions for available permanent charged sites restricting the sorption of potentially toxic metal cations onto these sites at low $\mathrm{pH}$ values. In contrast, at high $\mathrm{pH}$ values, the competition becomes feeble; thus, more metal is adsorbed $[23,24]$. In other words, the solubility of most trace metals becomes limited, leading to their low concentrations as the soil $\mathrm{pH}$ becomes higher [25]. In [26], they demonstrated the solubility of $\mathrm{Zn}$ at different levels of $\mathrm{pH}$. At $\mathrm{pH}$ 7 , only $1 \mathrm{mg} / \mathrm{L}$ of $\mathrm{Zn}$ of the $1200 \mathrm{mg} / \mathrm{kg}$ total $\mathrm{Zn}$ was present in soil solution, while at $\mathrm{pH} 6$ and 5, the concentrations of $\mathrm{Zn}$ in soil solution were observed at $100 \mathrm{mg} / \mathrm{L}$ and $40 \mathrm{mg} / \mathrm{L}$. From the current study, the Chini soil ( $\mathrm{pH}$ 3.97) and Langkawi soil ( $\mathrm{pH} 4.23$ ) exhibited low concentrations of $\mathrm{Pb}$ and $\mathrm{Zn}$, while the Kenyir soil ( $\mathrm{pH}$ 4.83) contained higher concentrations of $\mathrm{Pb}$ and $\mathrm{Zn}$. Besides adsorption, soil $\mathrm{pH}$ is also affected by the precipitation of carbonates, chlorides, phosphates, hydroxide, and sulphates. The application of lime and apatite causes high $\mathrm{pH}$, directly decreasing $\mathrm{Cu}$ and $\mathrm{Cd}$ concentrations [27].

Soil quality indicators are physical, chemical, and biological properties that can be assessed to monitor soil changes [28,29]. The color of soils indicates the availability of soil organic matter, i.e., organic-mineral complexes. Commonly, dark soil contains more humus than light soil. Andosols (dark soils) are characterized by a low L* value, indicating higher $\mathrm{C}, \mathrm{N}$, and Fe concentrations. In contrast, yellowish soil has a higher $\mathrm{L}^{*}$ value, representing lower $\mathrm{C}, \mathrm{N}$, and Fe [30].

\subsection{Extractable Organic Matter Using Autoclaved Methods}

Extraction technologies are often based on temperature and pressure strength using organic or aqueous solvents [31]. Bioactive compounds exhibit varying polarity, solubility, and chemical stability; thus, the appropriate pressure and solvent type should be selected to extract targeted bioactive compounds [32]. Temperature is another parameter that influences the extraction process. More organic matter could be extracted when autoclaved than from $24 \mathrm{~h}$ room temperature extraction. This is due to the disintegration of polysaccharide structures, alteration processes that influence the soil surface, and unknown reactions or nutrients within the soil matrix. Thus, the dissolved organic matter and ion concentrations could be enhanced in the liquid form [33]. Incubation at $20^{\circ} \mathrm{C}$ from $1 \mathrm{~h}$ to $24 \mathrm{~h}$ showed minimal changes in extractable organic carbon [34]. The author also found that increasing the temperature could narrow the $\mathrm{C}: \mathrm{N}$ ratio, indicating a higher composition of extractable organic nitrogen and $\mathrm{NH}_{4}$. A shorter extraction duration at room temperature was more desirable as the amount of extractable $\mathrm{C}$ and $\mathrm{N}$ did not change drastically. The carbohydrate and $\mathrm{N}$ (mineral) concentrations were significantly higher than with the longer extraction time [34]. Soil weathering is usually a slow process at low temperature $\left(\sim 28^{\circ} \mathrm{C}\right)$ and might not significantly change within a day [35].

The low temperature might not be sufficient to extract high OM because the heat energy is too low to surpass the activation energy and allows the disrupted molecules to be released to the extracts [36]. Water-extractable organic carbon and nitrogen indicated 
a huge difference between $45^{\circ} \mathrm{C}$ and $90{ }^{\circ} \mathrm{C}$, exhibiting a constant exponential profile in response to the increasing temperature [37]. The extracted DOM yield could be enriched by the elevated temperature $[33,38]$. Besides, extractable organic carbon can be enhanced by the autoclaving processes $[39,40]$. The incidence of highly extractable organic matter at the autoclave temperature of $121^{\circ} \mathrm{C}$ is probably due to the disintegration of heat to the stable compounds (C, N, P, and other compounds), releasing them into the extract. This process surpasses the activation energy of certain molecules to cleave the chemical bonds [41,42].

Total organic $\mathrm{N}$ was contributed the most by $\mathrm{NH}_{4}{ }^{+}$(about $27-74 \%$ ), followed by $\mathrm{NO}_{3}(10-54 \%)$. Based on a study by [43], the concentration of free $\mathrm{N}$ in soil extracts was dominated by $\mathrm{NH}_{4}{ }^{+}$, with $54-72 \%$ of total $\mathrm{N}$, while $\mathrm{NO}_{3}$ contributed about $1-4 \%$ total $\mathrm{N}$ in forest and grassland soils. In [44], it was suggested that the increase of extraction temperature might promote the breakdown of organic $\mathrm{N}$ to more soluble molecules such as peptides, amino acids, and amino sugars, creating a pool rich in these molecules.

The $\mathrm{pH}$ changes in the autoclaved soil extract were probably due to the release of organic acids from the DOM pool, and the data was supported by the spectrum using $\mathrm{C}-\mathrm{CP} / \mathrm{MS}$ spectra, where the carboxylic peak declined [33]. The immensity of the decrease can be seen upon the soils' initial acid-base conditions [45]. Two different studies reported that autoclave could reduce the $\mathrm{pH}$ of clay soil, whereas the other study observed no $\mathrm{pH}$ changes in silt loam soils [46]. Since the initial soils were already in acidic form, the results were expected. In contrast, Eutric Fluvisol soil with an initial $\mathrm{pH}$ of 7.44 changed to 7.77 after double steam sterilization due to the release of bases from the organic matter [47].

\subsection{Hydrophobic and Hydrophilic Fractions of Soil Extracts}

Our results suggested that the concentrations of humic and nonhumic substances could be increased by autoclaving and prolonging the process duration, supported by the analysis obtained from Tables 3 and 4 . The carbon content in humic acid from four different Mumbai regions ranged from $17 \%$ to 53\% [48]. Meanwhile, [49] conducted a thermodynamics stability study of humus at $10,20,40$, and $55^{\circ} \mathrm{C}$. The author observed that the transformation of fulvic acids to humic acids were significantly higher at 40 and $55^{\circ} \mathrm{C}$. The authors of [50] reported considerable changes were observed in the UV-Vis spectra $(280 \mathrm{~nm})$ of humic acid solutions at a temperature of $95^{\circ} \mathrm{C}$ for $24 \mathrm{~h}$ storage than at $80^{\circ} \mathrm{C}$. The study also compared the storage time at $24 \mathrm{~h}$ and a week, where the substantial changes observed at $95^{\circ} \mathrm{C}$ for $24 \mathrm{~h}$ was comparable to the storage time for 1 week at $80^{\circ} \mathrm{C}$. The temperature-dependent changes signified more condensed polyaromatic structures by condensing phenolic and carboxylic groups of the humic acids [51]. Humic acids under higher temperature and extended durations underwent irreversible changes at $80^{\circ} \mathrm{C}$ through water loss. At $95^{\circ} \mathrm{C}$ and above, the changes were probably due to the release of chemisorbed water molecules or water molecules from the condensation process, which could exist among the adjacent carboxylic and alcoholic groups of humic acids [50]. In [52] and [53] it was revealed that the humic fraction became the main organic component with 2- to 3 -fold increase upon increased heating times at $<250{ }^{\circ} \mathrm{C}$. The study by [53] also concluded that at high temperature $\left(300^{\circ} \mathrm{C}\right)$, humic fraction decreased with increased heating time, and at $200^{\circ} \mathrm{C}$, the proportion of the humic fraction increased with increased heating time. The main factor in humic structure changes was demonstrated by [54,55], i.e., structural changes at a high temperature $\left(350^{\circ} \mathrm{C}\right)$ were due to various factors, including increased aromatic content, removal of oxygen-containing functional groups, heterocyclic formation $\mathrm{N}$ compounds, and the reduction of the chain length of alkyl compounds. The ${ }^{13} \mathrm{C}$ NMR spectra results showed that unheated soils contained high alkyl and O-alkyl with low aromatic and carboxyl $\mathrm{C}$ contents, while heated samples contained high aromatics and carboxyl $\mathrm{C}$ with low alkyl and $\mathrm{O}-$ alkyl. The basic structure of humic acids remained unchanged up to $250{ }^{\circ} \mathrm{C}$, and decarboxylation occurred above $300{ }^{\circ} \mathrm{C}$. These studies concluded that the increase of temperature and heating duration might extract more humic substances without altering their structure. 


\section{Materials and Methods}

Three mineral soil samples from Peninsular Malaysia were collected for this study, Sg. Beruang near Chini Lake, Pahang $\left(3^{\circ} 26^{\prime} 01.3^{\prime \prime} \mathrm{N} 102^{\circ} 55^{\prime} 08.0^{\prime \prime} \mathrm{E}\right)$, Singa Besar Island, Langkawi Island, Kedah $\left(6^{\circ} 12^{\prime} 51.2^{\prime \prime} \mathrm{N} 99^{\circ} 44^{\prime} 47.9^{\prime \prime} \mathrm{E}\right)$ and Sah Kecil Island, a small island located at Kenyir Lake $\left(5^{\circ} 05^{\prime} 01.7^{\prime \prime} \mathrm{N} 102^{\circ} 48^{\prime} 08.6^{\prime \prime} \mathrm{E}\right)$. The location of sampling sites was illustrated based on Figure S1. The random technique was conducted for soil sampling, according to the United State Department of Agriculture (USDA) method suggested by [56]. Figure 6 illustrates the process of soil collection. Soil surface or O horizon of about $15 \mathrm{~cm}$ from the soil surface was removed before the sample was collected. Five cores with uniform characteristics were collected about $1 \mathrm{~kg}$ each before being homogenized into one composite. Coarse particles such as stones, wood, and roots were removed, and the samples were dried at $60^{\circ} \mathrm{C}$ until moisture was completely removed. Upon completion, the dried soils were ground to powder and sieved using a 2-mm stainless steel sieve. The selected soil characteristics and analytical method are shown in Table 5.

$2 \mathrm{~m}$

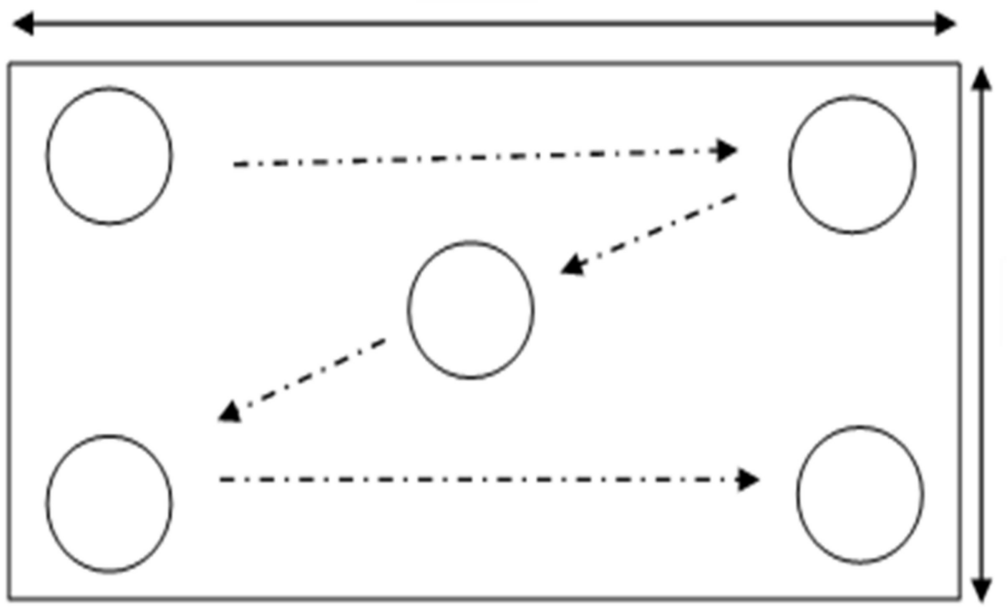

$2 \mathrm{~m}$

Figure 6. Random sampling method at 5 different points in a designated area [53].

Table 5. Selected parameters and analytical method.

\begin{tabular}{ccc}
\hline Parameters & Unit & Analysis Method \\
\hline pH & - & APHA 4500-H B \\
Nitrogen, $\mathrm{N}$ & $\%$ & MS 417L PART 3: 1994 \\
Phosphorus, $\mathrm{P}$ & $\%$ & MS 678: PART 8 \\
Potassium, $\mathrm{K}$ & $\%$ & (MS 417: PART 3: 1994): MS 678: \\
Total organic carbon & $\%$ & PART VI to IX: 1980 (APHA 3500 K)) \\
Arsenic, As & $\mathrm{mg} / \mathrm{kg}$ & MS 678: PART 3A: 1980 \\
Iron, Fe & $\mathrm{mg} / \mathrm{kg}$ & USEPA 1311 (APHA 3111-B) \\
Cadmium, Cd & $\mathrm{mg} / \mathrm{kg}$ & USEPA 1311 (APHA 3111-B) \\
Chromium, Cr & $\mathrm{mg} / \mathrm{kg}$ & USEPA 1311 (APHA 3111-B) \\
Chromium Hexavalent & $\mathrm{mg} / \mathrm{kg}$ & USEPA 1311 (APHA 3111-B) \\
Lead, Pb & $\mathrm{mg} / \mathrm{kg}$ & USEPA 1311 (APHA 3111-B) \\
Copper, Cu & $\mathrm{mg} / \mathrm{kg}$ & USEPA 1311 (APHA 3111-B) \\
Nickel, Ni & $\mathrm{mg} / \mathrm{kg}$ & USEPA 1311 (APHA 3111-B) \\
Zinc, Zn & $\mathrm{mg} / \mathrm{kg}$ & USEPA 1311 (APHA 3111-B) \\
Mercury, Hg & $\mathrm{mg} / \mathrm{kg}$ & USEPA 1311 (APHA 3111-B) \\
Silver, Ag & $\mathrm{mg} / \mathrm{kg}$ & USEPA 1311 (APHA 3111-B) \\
\hline & $\%$ (A) & USDA/NRCS Soil Taxonomy \\
Sand & $\%$ & USDA/NRCS Soil Taxonomy \\
Silt & Particle Size Distribution (PSD) & USDA/NRCS Soil Taxonomy \\
Clay & &
\end{tabular}




\subsection{Soil Extraction}

The extraction process was carried out in triplicate. Aqueous extraction was done according to previous studies with slight modification $[57,58]$. Five different aqueous extraction treatments were conducted (Table 6). Approximately $20 \mathrm{~g}$ of each processed soil sample was put into Schott bottles with $200 \mathrm{~mL}$ ultra-pure water (1:10) and handshaken vigorously (end to end) for $5 \mathrm{~min}$. For the room temperature extraction, samples were incubated for $24 \mathrm{~h}(24 \mathrm{~h})$ in the dark. Meanwhile, for the high-temperature aqueous extraction, the autoclave SX-500 (Tomy Seiko Co., Ltd., Tokyo, Japan) was used. The samples were autoclaved for $1 \mathrm{~h}$ and $2 \mathrm{~h}$ with a slight change of temperature, i.e., $105^{\circ} \mathrm{C}$ and $121^{\circ} \mathrm{C}$. Details about the procedure are listed in Table 6. After incubation, the bottles were hand-shaken for $1 \mathrm{~min}$ to resuspend the soil. The samples were centrifuged using the Beckman Allegra X-30R (Beckman Coulter, Indianapolis, IN, USA) centrifuge at $2500 \mathrm{rpm}$ for $15 \mathrm{~min}$. The supernatant was filtered using $0.7 \mu \mathrm{m}$ Whatman Glass Microfiber Filter (GF/F) (Cytiva, Maidstone, United Kingdoms), and the filtrate was stored at $-20{ }^{\circ} \mathrm{C}$ in Revco, ULT-390-10 freezer (Thermo Fisher Scientific, Waltham, Massachusetts, United States) for further analysis.

Table 6. Type of soil extraction methods and the procedure used.

\begin{tabular}{cc}
\hline Extraction Methods & Procedure \\
\hline Natural Extraction 24 Hours $(24 \mathrm{~h})$ & Extracted at room temperature for $24 \mathrm{~h}$ incubation \\
Autoclave $105^{\circ} \mathrm{C}\left(105^{\circ} \mathrm{C}\right)$ & Extracted at $105^{\circ} \mathrm{C}$ using autoclave for $1 \mathrm{~h}$ \\
Autoclave $121^{\circ} \mathrm{C}\left(121^{\circ} \mathrm{C}\right)$ & Extracted at $121^{\circ} \mathrm{C}$ using autoclave for $1 \mathrm{~h}$ \\
Autoclave $105^{\circ} \mathrm{C}\left(105^{\circ} \mathrm{C} 2 \times\right)$ & $\begin{array}{c}\text { Extracted at } 105^{\circ} \mathrm{C} \text { using autoclave for } 1 \mathrm{~h} \text {, cooled } \\
(\approx 30 \mathrm{~min}) \text { and autoclaved for another } 1 \mathrm{~h}\end{array}$ \\
Autoclave $121^{\circ} \mathrm{C}\left(121^{\circ} \mathrm{C} 2 \times\right)$ & $\begin{array}{r}\left(\approx x+r a c t \text { at } 121^{\circ} \mathrm{C} \text { using autoclave for } 1 \mathrm{~h}, \text { cooled }\right. \\
(\approx 30 \mathrm{~min}) \text { and autoclaved for another } 1 \mathrm{~h}\end{array}$ \\
\hline
\end{tabular}

\subsection{Macronutrient Analysis}

Total dissolved nitrogen (TDN) and total dissolved phosphorus (TDP) of the extracts were measured using a portable spectrophotometer, Lovibond MD600 (The Tintometer Limited, Amesbury, UK). Each parameter was measured using designated reagents and procedure according to the given instructions in the manual. Dissolved organic carbon (DOC) of extracts was measured as nonpurgeable organic carbon (NPOC) using Shimadzu TOC-L CSH (Shimadzu, Kyoto, Japan) The sample was transferred into a $9 \mathrm{~mL}$ vial, and $1 \%$ of the total volume of the sample was added with $2 \mathrm{M}$ hydrochloric acid $(\mathrm{HCl})$ to remove volatile carbon. Since the NPOC was measured using high sensitivity catalyst, manual dilution of the concentrated samples was done. Triplicate samples $(n=3)$ for each treatment were measured for statistical analysis.

\subsection{Hydrophobic and Hydrophilic Fraction}

In this study, the DOM fractionation was conducted based on hydrophobic and hydrophilic interactions using ion-exchange resins (XAD-8 resins, obtained from National of Environmental Studies, Tsukuba, Ibaraki, Japan). DOM fractionation was obtained by a two-step procedure described in Figure 7 [59,60]. Fractionation of samples was described based on hydrophobic (absorbed, known as HS) and hydrophilic (nonabsorbed, known as $\mathrm{HiF}$ ) fractions. All glassware used in this operation was precombusted at $450{ }^{\circ} \mathrm{C}$ for $4 \mathrm{~h}$. In the first step, DOM 1 (sample) was acidified to $\mathrm{pH} 2$ using $6 \mathrm{M} \mathrm{HCl}$ and then pumped through the Amberlite XAD-8 resin (20-60 mesh) using a peristaltic pump with Tygon tubing. The column was rinsed with a 1-2 bed volume of $0.1 \mathrm{M} \mathrm{HCl}$ to elute the HiF. HS was then eluted with $0.1 \mathrm{M}$ of sodium hydroxide $(\mathrm{NaOH})$. Both $\mathrm{HiF}$ and $\mathrm{HS}$ were collected and stored in Schott bottles. Figure 8 shows the schematic system of the auto fractionation system used in this experiment. 
Sample (DOC 1)

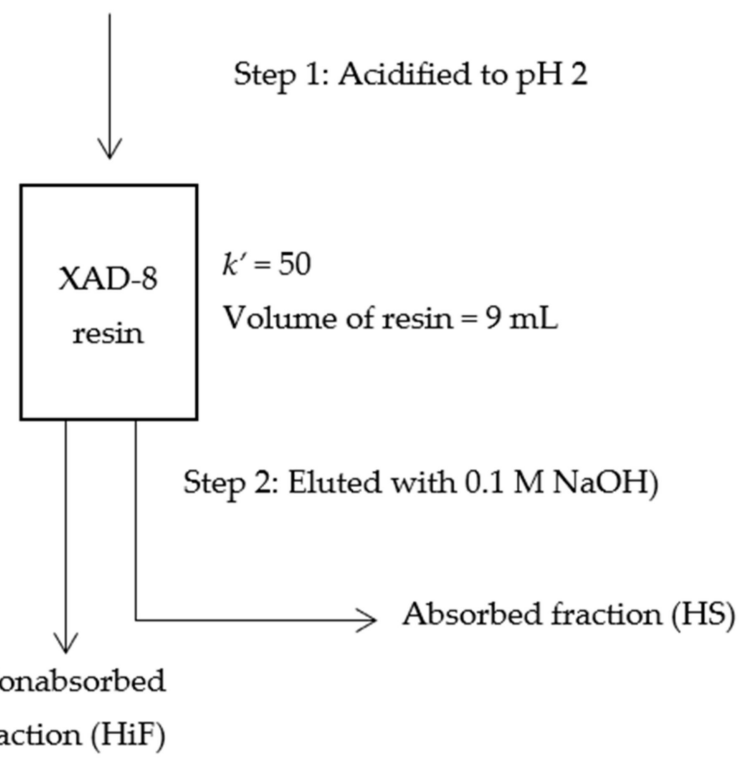

Figure 7. Experimental procedure for separation into absorbed fractions and unabsorbed fractions using soil samples. Details procedures explained and described in Figure 8.

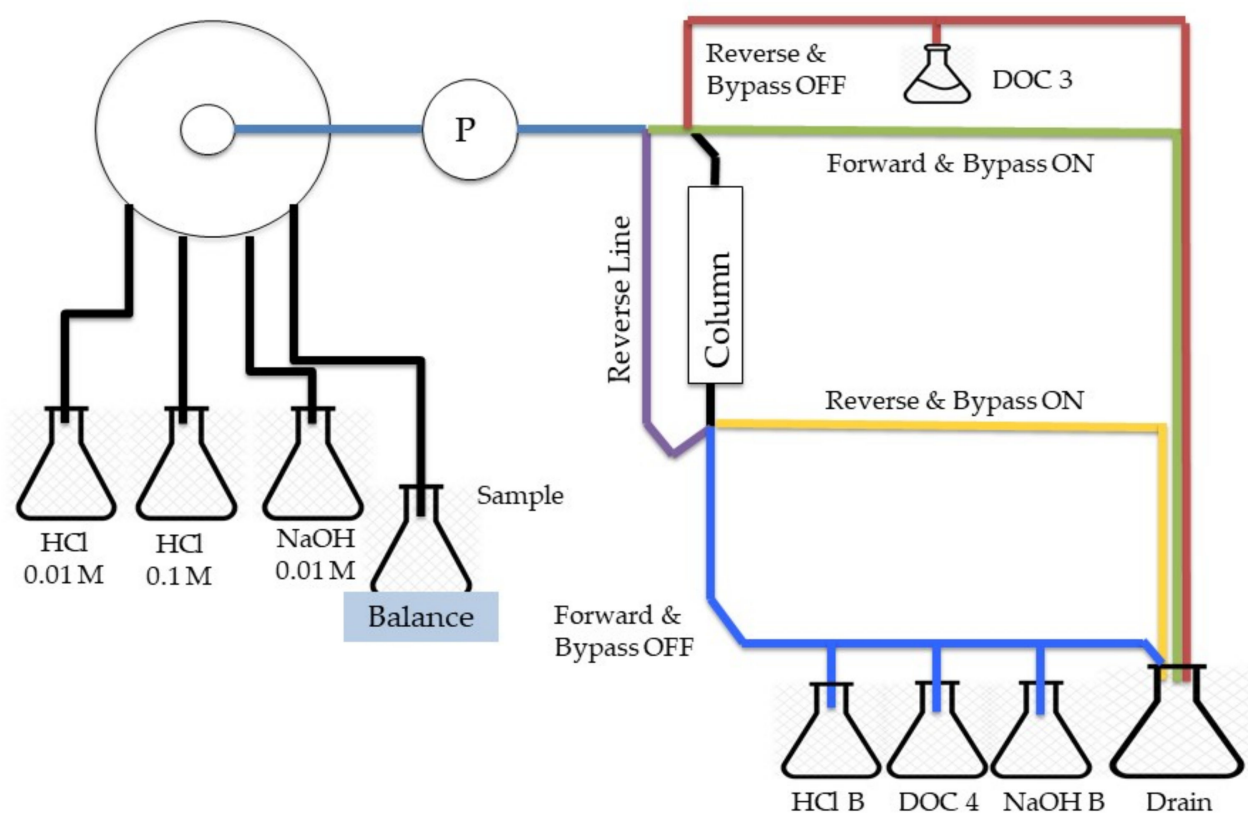

Figure 8. Schematic of Auto Fractionation System.

In this experiment, the column capacity factor $k^{\prime}$ through XAD-8 resin was set at 50 . Factor $k^{\prime}$ can be defined as the ratio between the sum of organic matter absorbed onto XAD resin/the sum of organic matter not absorbed onto XAD resin. Every organic matter has its own $k^{\prime}$ factor and breaking the hydrophobic/hydrophilic fraction could be defined in a situation where $50 \%$ of organic matter with $k^{\prime}=50-100$ was absorbed onto XAD resin. Two different experiments were conducted where [61] used $k^{\prime}=50$, and [62] used $k^{\prime}=100$. So, $k^{\prime}$ has been used as the parameter for defining HS in the fractionation process. The following equation has been suggested by [59] regarding the relationship between sample volume and $k^{\prime}$ : 


$$
k \prime=\frac{\mathrm{V}_{\mathrm{el}}}{2 \mathrm{~V}_{0}}-1
$$

where,

$\mathrm{V}_{\mathrm{el}}=$ sample volume

$\mathrm{V}_{0}=$ volume of XAD-8 resin ( $65 \%$ bulk column volume)

In this experiment, the volume of XAD-8 resin was measured at $9 \mathrm{~mL}$ and $k^{\prime}=50$. Therefore, the calculation of total volume of sample should be:

$$
\mathrm{V}_{\mathrm{el}}=(50+1) \times(2 \times(9 \mathrm{~mL} \times 0.65))
$$

\subsection{Statistical Analysis}

All results were analyzed using one-way analysis variance (ANOVA) and Tukey post hoc at $p<0.05$. The significant difference between treatment was calculated using SPSS Software at a $95 \%$ interval level. All samples were analyzed in triplicate to obtain the average values for each analysis.

\section{Conclusions}

In conclusion, the results suggest that the composition of extractable organic matter varies using different extraction methods, and the recovery of organic matter depends on the initial conditions of soil and heat provided during the autoclaving process. Soil extracts using the autoclave yielded more DOC, TDN, TDP and ammonium nitrate compared to natural extraction, up to 3.0, 1.3,1.2 and 1.4 times higher, respectively. Nevertheless, the autoclave treatment can be proposed as a standard procedure to extract high organic matter, at least in this study. The best treatment in terms of the highest extractable organic matter was noted in the $121^{\circ} \mathrm{C} 2 \times$ autoclave approach. A higher fraction of soil extracts can also be recovered in autoclaved soil without altering the basic structure of humic and nonhumic substances. The recovered organic matter information can be utilized to understand its various applications, especially as a growth promoter for targeted microorganisms. The study could also reduce the cost and increase the effectiveness of existing artificial media for microbial growth.

Supplementary Materials: The following are available online. Figure S1: Map of sampling sites in this study: (A) Sg. Beruang near Chini Lake, Pahang ( $\left.3^{\circ} 26^{\prime} 01.3^{\prime \prime} \mathrm{N} 102^{\circ} 55^{\prime} 08.0^{\prime \prime} \mathrm{E}\right)$; (B) Singa Besar Island, Langkawi Island, Kedah $\left(6^{\circ} 12^{\prime} 51.2^{\prime \prime} \mathrm{N} 99^{\circ} 44^{\prime} 47.9^{\prime \prime} \mathrm{E}\right)$; and (C) Sah Kecil Island, Kenyir Lake $\left(5^{\circ} 05^{\prime} 01.7^{\prime \prime} \mathrm{N} 102^{\circ} 48^{\prime} 08.6^{\prime \prime} \mathrm{E}\right)$.

Author Contributions: Conceptualization, M.F.A. and E.F.H.; methodology, W.M.I.W.M.Z.; soft-ware, F.S.; validation, N.S.Y., M.F.A.; formal analysis, K.K.; investigation, N.F.D.; resources, W.M.I.W.M.Z.; data curation, W.M.I.W.M.Z., N.S.Y.; writing-original draft preparation, W.M.I.W.M.Z., N.S.Y.; writing-review and editing, N.K.; visualization, H.A.; supervision, V.S.K.; project administration, K.K.; funding acquisition, M.N.M. All authors have read and agreed to the published version of the manuscript.

Funding: This research was funded by the Ministry of Higher Education Malaysia (MOHE) and Japan Science and Technology Agency (JST)/Japan International Cooperation Agency (JICA), (Grant No. JPMJSA1509).

Institutional Review Board Statement: Not applicable.

Informed Consent Statement: Not applicable.

Data Availability Statement: Not applicable.

Acknowledgments: Special thanks to the Ministry of Higher Education Malaysia (MOHE), Japan Science and Technology Agency (JST)/Japan International Cooperation Agency (JICA), through the project for JPMJSA1509), and the SATREPS-COSMOS Matching Fund.

Conflicts of Interest: The authors declare no conflict of interest.

Sample Availability: Samples of the compounds are not available. 


\section{References}

1. He, W.; Chen, M.; Schlautman, M.A.; Hur, J. Dynamic exchanges between DOM and POM pools in coastal and inland aquatic ecosystems: A review. Sci. Total Environ. 2016, 551-552, 415-428. [CrossRef] [PubMed]

2. Watanabe, M.M. Freshwater Culture media. In Algal Culture Techniques; Andersen, R.A., Ed.; Elsevier Academic Press: London, UK, 2005; p. 13.

3. Marschner, B.; Kalbitz, K. Controls of bioavailability and biodegradability of dissolved organic matter in soils. Geoderma 2003, 113, 211-235. [CrossRef]

4. Kalbitz, K.; Solinger, S.; Park, J.-H.; Michalzik, B.; Matzner, E. Controls on the dynamics of dissolved organic matter in soils: A review. Soil Sci. 2000, 165, 277-304. [CrossRef]

5. Cotrufo, M.F.; Soong, J.L.; Horton, A.J.; Campbell, E.E.; Haddix, M.L.; Wall, D.H.; Parton, W.J. Formation of soil organic matter via biochemical and physical pathways of litter mass loss. Nat. Geosci. 2015, 8, 776-779. [CrossRef]

6. Baldock, J.; Manning, N.; Vickerstaff, S. Social Policy, 3rd ed.; Oxford University Press: Oxford, UJ, USA, $2007 ;$ p. 722.

7. Kleber, M.; Sollins, P.; Sutton, R. A conceptual model of organo-mineral interactions in soils: Self-assembly of organic molecular fragments into zonal structures on mineral surfaces. Biogeochemistry 2007, 85, 9-24. [CrossRef]

8. Von Lützow, M.; Kögel-Knabner, I.; Ludwig, B.; Matzner, E.; Flessa, H.; Ekschmitt, K.; Guggenberger, G.; Marschner, B.; Kalbitz, K. Stabilization mechanisms of organic matter in four temperate soils: Development and application of a conceptual model. J. Plant Nutr. Soil Sci. 2008, 171, 111-124. [CrossRef]

9. Piccolo, A. The supramolecular structure of humic substances: A novel understanding of humus chemistry and implications in soil science. Adv. Agron. 2002, 75, 57-134.

10. McKee, G.A.; Soong, J.L.; Caldéron, F.; Borch, T.; Cotrufo, M.F. An integrated spectroscopic and wet chemical approach to investigate grass litter decomposition chemistry. Biogeochemistry 2016, 128, 107-123. [CrossRef]

11. Huang, Y.; Eglinton, G.; Van Der Hage, E.R.E.; Boon, J.J.; Bol, R.; Ineson, P. Dissolved organic matter and its parent organic matter in grass upland soil horizons studied by analytical pyrolysis techniques. Eur. J. Soil Sci. 1998, 49, 1-15. [CrossRef]

12. Hanke, D.; Dick, D.P. Organic Matter Stocks and the Interactions of Humic Substances with Metals in Araucaria Moist Forest Soil with Humic and Histic Horizons. Rev. Bras. Ciência Solo 2017, 41, 41. [CrossRef]

13. Spaak, G. Investigating the Potential of Dissolved Organic Matter (DOM) Induced Denitrification in Dutch Groundwater. Ph.D. Thesis, Utrecht University, Utrecht, The Netherlands, April 2014.

14. Thurman, E.M. Amount of Organic Carbon in Natural Waters BT-Organic Geochemistry of Natural Waters; Springer: Dordrecht, The Netherlands, 1985; pp. 7-65.

15. McDonald, S.; Bishop, A.G.; Prenzler, P.D.; Robards, K. Analytical chemistry of freshwater humic substances. Anal. Chim. Acta 2004, 527, 105-124. [CrossRef]

16. Orlov, D. Humic Substances of Soils and General Theory of Humification; Apple Academic Press: London, UK, 2020.

17. Essington, M.E. Soil and Water Chemistry: An Integrative Approach; CRC Press: London, UK, 2015.

18. Schwesig, D.; Göttlein, A.; Haumaier, L.; Blasek, R.; Ilgen, G. Soil Organic Matter Extraction Using Water at High Temperature and Elevated Pressure (ASE) as Compared to Conventional Methods. Int. J. Environ. Anal. Chem. 1999, 73, 253-268. [CrossRef]

19. Masoom, H.; Courtier-Murias, D.; Farooq, H.; Soong, R.; Kelleher, B.P.; Zhang, C.; Maas, W.E.; Fey, M.; Kumar, R.; Monette, M.; et al. Soil Organic Matter in Its Native State: Unravelling the Most Complex Biomaterial on Earth. Environ. Sci. Technol. 2016, 50, 1670-1680. [CrossRef]

20. Khairil, M.; Wan Juliana, W.A.; Nizam, M.S.; Razi Idris, W.M. Soil properties and variation between three forest types in tropical watershed forest of Chini Lake, Peninsular Malaysia. Sains Malays. 2014, 43, 1635-1643.

21. Gasim, M.B.; Ismail, B.; Mir, S.-I.; Rahim, S.A.; Toriman, M.E. The Physico-chemical Properties of Four Soil Series in Tasik Chini, Pahang, Malaysia. Asian J. Earth Sci. 2011, 4, 75-84. [CrossRef]

22. Rieuwerts, J.; Thornton, I.; Farago, M.; Ashmore, M. Factors influencing metal bioavailability in soils: Preliminary investigations for the development of a critical loads approach for metals. Chem. Speciat. Bioavailab. 1998, 10, 61-75. [CrossRef]

23. Huang, B.; Li, Z.; Huang, J.; Guo, L.; Nie, X.; Wang, Y.; Zhang, Y.; Zeng, G. Adsorption characteristics of Cu and Zn onto various size fractions of aggregates from red paddy soil. J. Hazard. Mater. 2014, 264, 176-183. [CrossRef]

24. Bech, J.; Abreu, M.M.; Chon, H.-T.; Roca, N. Remediation of Potentially Toxic Elements in Contaminated Soils. In PHEs, Environment and Human Health; Metzler, J.B., Ed.; Springer: Dordrecht, The Netherland, 2014; pp. 253-308.

25. Kabata-Pendias, A. Trace Elements in Soils and Plants, Fourth ed.; Springer: Berlin/Heidelberg, Germany, 2010.

26. Förstner, U. Land Contamination by Metals: Global Scope and Magnitude of Problem in Metal Speciation and Contamination of Soil; Lewis Publisher: Boca Raton, FL, USA, 1995.

27. Cui, H.; Fan, Y.; Fang, G.; Zhang, H.; Su, B.; Zhou, J. Leachability, availability and bioaccessibility of Cu and Cd in a contaminated soil treated with apatite, lime and charcoal: A five-year field experiment. Ecotoxicol. Environ. Saf. 2016, 134, 148-155. [CrossRef]

28. Asadu, C.L.A.; Chibuike, G.U. Contributions of organic matter, clay and silt to the effective CEC of soils of different land use history. Adv. Nat. Appl. Sci. 2015, 9, 110-115.

29. Nciizah, A.D.; Wakindiki, I.I. Physical indicators of soil erosion, aggregate stability and erodibility. Arch. Agron. Soil Sci. 2014, 61, 827-842. [CrossRef]

30. Moritsuka, N.; Matsuoka, K.; Katsura, K.; Sano, S.; Yanai, J. Soil color analysis for statistically estimating total carbon, total nitrogen and active iron contents in Japanese agricultural soils. Soil Sci. Plant Nutr. 2014, 60, 475-485. [CrossRef] 
31. Molino, A.; Mehariya, S.; Di Sanzo, G.; Larocca, V.; Martino, M.; Leone, G.P.; Marino, T.; Chianese, S.; Balducchi, R.; Musmarra, D. Recent developments in supercritical fluid extraction of bioactive compounds from microalgae: Role of key parameters, technological achievements and challenges. J. CO2 Util. 2020, 36, 196-209. [CrossRef]

32. Da Silva, R.P.; Rocha-Santos, T.A.; Duarte, A.C. Supercritical fluid extraction of bioactive compounds. TrAC Trends Anal. Chem. 2016, 76, 40-51. [CrossRef]

33. Berns, A.E.; Philipp, H.; Narres, H.-D.; Burauel, P.; Vereecken, H.; Tappe, W. Effect of gamma-sterilization and autoclaving on soil organic matter structure as studied by solid state NMR, UV and fluorescence spectroscopy. Eur. J. Soil Sci. 2008, 59, 540-550. [CrossRef]

34. Teves-Costa, P.; Oliveira, C.S.; Senos, M.L. Effects of local site and building parameters on damage distribution in Angra do Heroísmo-Azores. Soil Dyn. Earthq. Eng. 2007, 27, 986-999. [CrossRef]

35. Yaacob, N.; Ahmad, M.; Kawasaki, N.; Maniyam, M.; Abdullah, H.; Hashim, E.; Sjahrir, F.; Zamri, W.W.M.; Komatsu, K.; Kuwahara, V. Kinetics Growth and Recovery of Valuable Nutrients from SE-Langor Peat Swamp and Pristine Forest Soils Using Different Extraction Methods as Potential Microalgae Growth Enhancers. Molecules 2021, 26, 653. [CrossRef]

36. De Oliveira, R.L.; da Silva, O.S.; Converti, A.; Porto, T.S. Thermodynamic and kinetic studies on pectinase extracted from Aspergillus aculeatus: Free and immobilized enzyme entrapped in alginate beads. Int. J. Biol. Macromol. 2018, 115, 1088-1093. [CrossRef]

37. Chantigny, M.H.; Curtin, D.; Beare, M.H.; Greenfield, L.G. Influence of Temperature on Water-Extractable Organic Matter and Ammonium Production in Mineral Soils. Soil Sci. Soc. Am. J. 2010, 74, 517-524. [CrossRef]

38. Jamien, F.M.; Embong, Z.; Tajudin, S.A.A.; Ahmad, S.; Lazim, A.M. The optimization of heating temperature for carbon extraction from peat soil. IOP Conf. Ser. Mater. Sci. Eng. 2018, 298, 12019. [CrossRef]

39. Liegel, L.H. Effects of sterilization procedures on the biological, chemical, and physical properties of soils-A review. Turrialba 1986, 36, 11-19.

40. McNamara, N.; Black, H.; Beresford, N.; Parekh, N. Effects of acute gamma irradiation on chemical, physical and biological properties of soils. Appl. Soil Ecol. 2003, 24, 117-132. [CrossRef]

41. Truhlar, D.G. Interpretation of the activation energy. J. Chem. Educ. 1978, 55, 309. [CrossRef]

42. Steinweg, J.M.; Jagadamma, S.; Frerichs, J.; Mayes, M.A. Activation Energy of Extracellular Enzymes in Soils from Different Biomes. PLoS ONE 2013, 8, e59943. [CrossRef] [PubMed]

43. Inselsbacher, E. Recovery of individual soil nitrogen forms after sieving and extraction. Soil Biol. Biochem. 2014, 71, 76-86. [CrossRef]

44. Martin, M.; Portetelle, D.; Michel, G.; Vandenbol, M. Microorganisms living on macroalgae: Diversity, interactions, and biotechnological applications. Appl. Microbiol. Biotechnol. 2014, 98, 2917-2935. [CrossRef]

45. Razavi, D.S.; Lakzian, A. Evaluation of chemical and biological consequences of soil sterilization methods. Casp. J. Environ. Sci. 2007, 5, 87-91.

46. Wolf, B.M.; Niedzwiedzki, D.M.; Magdaong, N.C.M.; Roth, R.; Goodenough, U.; Blankenship, R.E. Characterization of a newly isolated freshwater Eustigmatophyte alga capable of utilizing far-red light as its sole light source. Photosynth. Res. 2017, 135, 177-189. [CrossRef]

47. Dietrich, P.; Cesarz, S.; Eisenhauer, N.; Roscher, C. Effects of steam sterilization on soil abiotic and biotic properties. Soil Org. 2000, 92, 99-108.

48. Mulani, K.; Deshpande, H. Humic acid analysis for comparison of soil samples: A forensic perspective. Nucl. Magn. Reson. 2018, $11,12$.

49. DouA, S. The thermodynamics stability of soil humic and fulvic acids. In Proceedings of the 19th World Congress of Soil Science: Soil Solutions for a Changing World, Brisbane, Australia, 1-6 August 2010; Symposium 2.2.1 Biogeochemical interfaces in soils. pp. 20-23.

50. Kolokassidou, C.; Pashalidis, I.; Costa, C.; Efstathiou, A.; Buckau, G. Thermal stability of solid and aqueous solutions of humic acid. Thermochim. Acta 2007, 454, 78-83. [CrossRef]

51. Fuentes, M.; González-Gaitano, G.; García-Mina, J.M. The usefulness of UV-visible and fluorescence spectroscopies to study the chemical nature of humic substances from soils and composts. Org. Geochem. 2006, 37, 1949-1959. [CrossRef]

52. Francioso, O.; Montecchio, D.; Gioacchini, P.; Ciavatta, C. Thermal analysis (TG-DTA) and isotopic characterization (13C-15N) of humic acids from different origins. Appl. Geochem. 2005, 20, 537-544. [CrossRef]

53. Katsumi, N.; Yonebayashi, K.; Okazaki, M. Effects of heating on composition, degree of darkness, and stacking nanostructure of soil humic acids. Sci. Total Environ. 2016, 541, 23-32. [CrossRef]

54. González-Pérez, J.A.; González-Vila, F.J.; Almendros, G.; Knicker, H. The effect of fire on soil organic matter-A review. Environ. Int. 2004, 30, 855-870. [CrossRef]

55. Martín, G.A.; Vila, F.J.G. Wildfires, soil carbon balance and resilient organic matter in Mediterranean ecosystems. A review. Span. J. Soil Sci. 2020, 2, 8-33. [CrossRef]

56. Page-Dumroese, D.S.; Harvey, A.E.; Jurgensen, M.F. A Guide to Soil Sampling and Analysis on the National Forests of the Inland Northwest United States; Diane Publishing Company: Collingdale, PA, USA, 1995; pp. 1-11. [CrossRef]

57. Provasoli, L.; McLaughlin, J.J.A.; Droop, M.R. The development of artificial media for marine algae. Arch. Microbiol. 1957, 25, 392-428. [CrossRef] 
58. Anderson, B.H.; Magdoff, F.R. Autoclaving Soil Samples Affects Algal-Available Phosphorus. J. Environ. Qual. 2005, $34,1958-1963$. [CrossRef]

59. Komatsu, K.; Imai, A.; Kawasaki, N. Comparison between humic-like peaks in excitation-emission matrix spectra and resinfractionated humic substances in aquatic environments. Limnology 2019, 20, 109-120. [CrossRef]

60. Imai, A.; Fukushima, T.; Matsushige, K.; Kim, Y.-H.; Choi, K. Characterization of dissolved organic matter in effluents from wastewater treatment plants. Water Res. 2002, 36, 859-870. [CrossRef]

61. Leenheer, J.A. Comprehensive approach to preparative isolation and fractionation of dissolved organic carbon from natural waters and wastewaters. Environ. Sci. Technol. 1981, 15, 578-587. [CrossRef]

62. Thurman, E.M.; Malcolm, R.L. Preparative isolation of aquatic humic substances. Environ. Sci. Technol. 1981, 15, 463-466. [CrossRef] [PubMed] 